\section{Emergency aid voted for West German universities}

\section{Munich}

WEST German politicians last week approved an emergency aid package to relieve university overcrowding in certain highly popular fields just as a wave of student demonstrations reached a new high-water mark.

Chancellor Helmut Kohl and the minister-presidents of the 11 Länder (states) agreed on 15 December that federal and Länder governments would each contribute half of $\mathrm{Dm} 2,100$ million in university support spread over seven years beginning in 1989. The package had been suggested by West German Education Minister Jürgen Möllemann.

The programme details were left unclear, but much of the money is expected to be spent on creating a larger capacity in

\section{They won't allow our graduation robes, either!}

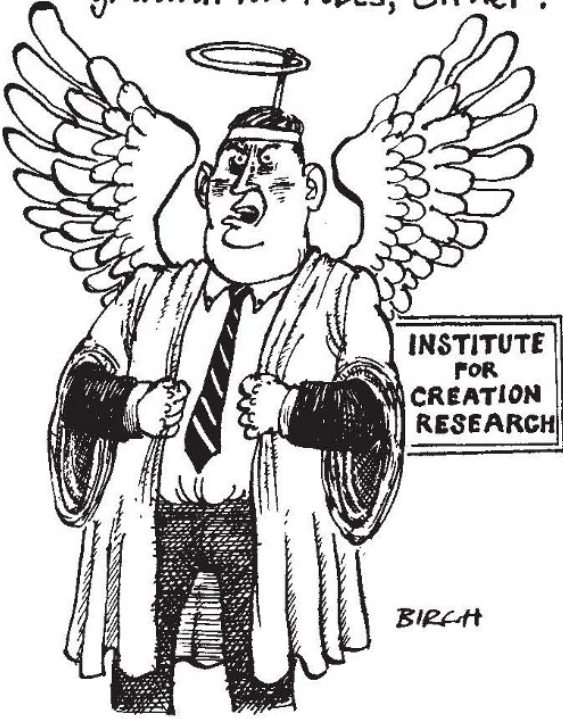

popular fields such as business studies and information sciences.

The emergency aid follows weeks of demonstrations in which tens of thousands of students have boycotted classes and taken to the streets. The protests, which began at a few big-city universities such as Frankfurt, Cologne and the Free University of Berlin, have spread to as many as 40 universities. They were scheduled to continue at some places until at least 20 December.

As each Länder has autonomy in deciding university policy, the student protests have focused on different issues around the country. But almost everywhere there are complaints about housing shortages, overcrowded lecture halls, unbearable conditions and a marked decline in the quality of education.

The chronic overcrowding that has become part and parcel of university education in the 1980s grew noticeably worse this semester.

In North Rhine-Westphalia, student anger was directed at the Land government for shifting positions away from the liberal arts and into natural sciences and engineering. In other Länder, there were calls for more student involvement in university affairs and new chairs in women's studies.

What made the protests unusual was the encouragement and support of university faculty and staff members. "Bad conditions for instruction of the students mean bad working conditions for the staff", said the employees' organization at the Free University of Berlin.

The demonstrations have differed dramatically from the famous 1968 student movement, when protesters sought to

\section{Berkeley}

Creationists in California are complaining of religious persecution, after the state Department of Education denied a small creationist school the right to award postgraduate degrees in science.

The Institute for Creation Research in San Diego is best known for its faculty member, Duane Gish, a frequent participant in public 'creation versus evolution' debates. Only 12 students have graduated from the institute's graduate school since it was founded in 1981, but their masters' degrees in biology, geology and astrogeophysics make them eligible for certification as secondary school science teachers.

A committee of scientists and educators assigned to evaluate the programme as part of the state re-approval process found that the students were not learning the

\section{Experts to Armenia}

\section{Washington}

A TEAM of earthquake experts from US universities, private industry and government agencies is scheduled to arrive in Armenia this week to help Soviet colleagues respond to the recent earthquake there. The team will offer advice on reconstruction efforts, and study how buildings were affected during the earthquake. An analysis of how well search and rescue efforts were carried out will be used as a basis for future preparedness efforts.

The team leaders are seismologist John Filson of the US Geological Survey and Mikhran Agbabian, chairman of the civil engineering department at the University of Southern California. Joseph Palca

change society and used universities as a platform to air their views. In 1988, students are concerned above all with the quality of their own education.

The West German Rectors' Conference (Westdeutsche Rektorenkonferenz or WRK), which represents the interests of universities, welcomed the programme as a step in the right direction, but warned that much more must be done before the real problems at universities can be solved. Investment in higher education has stagnated for a decade, said WRK president Hinrich Seidel, while the number of students has nearly doubled, to roughly 1.5 million this semester. The new money corresponds to just 2 per cent of the cost of running the universities, he said.

Seidel wants a "substantial portion" of the money to go to fields besides business and information sciences. $\mathrm{He}$ also expressed the fear that the new money might aggravate the economic differences between northern and southern Länder.

Steven Dickman

\title{
No graduate degrees for creationists
}

fundamentals of science because of the institute's strong focus on the biblical interpretation of creation. William Rukeyser, spokesman for the state Department of Education, says the department would be derelict in its duty if it allowed the institute to continue to award science degrees.

State school superintendent Bill Honig has clashed with creationists before over their political influence on the treatment of evolution in biology textbooks for secondary schools. The creationists accuse him of having a personal grudge against them.

"As a private Christian institution, we ought to be able to teach what we want", says Henry Morris, president of the institute.

Honig says the school may issue degrees in creationism or religion, but not science. "It's a consumer issue", he says. "If a person is going to get a degree in anything, the institution should be approved for quality in that area." Morris argues that the institute's science courses are very similar to those taught elsewhere, "except that the framework, which comes up every once in a while, is creationist instead of evolutionist". But Honig argues that biology, geology and astrophysics are based on fundamental assumptions about evolution and the age of the Earth and Universe that are incompatible with creationism.

The evaluation committee first voted 3 to 2 to approve the institute's programmes, despite the lack of scientific substance. But Honig convinced them that they should change their minds. "You don't have academic freedom to tell the public you're teaching something when you're not teaching it at all", he said. Marcia Barinaga 